Acta Regionalia et Environmentalica 2

Nitra, Slovaca Universitas Agriculturae Nitriae, 2019, pp. 25-33

\title{
ADVERSE AND BENEFICIAL EFFECTS OF WOODY BIOMASS FEEDSTOCK PLANTATIONS ON BIODIVERSITY AND WILDLIFE HABITATS
}

\author{
Sándor NÉMETHY1, 2, 3* , László SZEMETHY² \\ ${ }^{1}$ University of Gothenburg, Department of Conservation, Sweden \\ ${ }^{2}$ University of Pécs, Institute of Regional Development, Hungary \\ ${ }^{3}$ Eszterházy Károly University, Eger - Gyöngyös, Hungary
}

\begin{abstract}
Woody biomass feedstock is suitable for direct combustion, gasification, pyrolysis, ethanol or methanol production yielding heat, charcoal, pyrolysis oil, green electricity and bio-propellants. However, there are several issues concerning the environmental, social and economic sustainability of woody biomass production connected to land use, protection of wildlife habitats, conservation and remediation of landscapes. Establishing energy plantations on arable lands or on grasslands is generally considered as working against nature conservation, while setting them up in polluted areas or wastelands could be advantageous for wildlife, because of 1. more permanent cover that provides shelter and biomass for feeding, which is especially important in winter periods; 2 . higher architectural complexity of vegetation providing more place for nesting and feeding for wildlife; 3 . exploiting the advantages of root filtration, phytoremediation, or using less chemicals; 4. forbs in the undergrowth and young shoots able to provide better quality food for wildlife than the intensive monocultures. The solution is a complex management system, including land use, phytoremediation, waste and wastewater management and ecosystem-based planning incorporated in one dynamic structure.
\end{abstract}

Keywords: biomass production, biodiversity, phytoremediation, wildlife habitats, agroforestry, short rotation forestry (SRF), short rotation coppicing (SRC), polycyclic arboriculture

Energy production and use are realized at several levels: we can talk about local, regional, national and global energy systems and their location in natural terrestrial systems linked and interrelated to biogeochemical cycles, which are often altered by human activities. The production and use of renewable energy (with particular emphasis on bioenergy, solar power, wind and geothermal energy) is the key for all aspects of sustainability, including economic viability.

Agricultural lands occupy $37.4 \%$ of the earth's land surface (https://data.worldbank.org/indicator/AG.LND.AGRI. $\underline{\mathrm{ZS}}$ ). Agriculture and agriculture-related activities account for 44.4\% of methane (https://data.worldbank.org/indicator/ EN.ATM.METH.AG.ZS/) and $70 \%$ of global anthropogenic nitrous oxide emissions (https://data.worldbank.org/ indicator/EN.ATM.NOXE.AG.ZS). The best way to reduce these greenhouse gases is the substitution of fossil fuels for energy production by agricultural feedstocks (e.g. crop residues, dung and dedicated energy crops). In agriculture it is possible to establish combined production structures, which include organic, chemical-free crop production, the use of bio-energy plantations and other dedicated energy crops as biological filters, the application of biologically cleaned waste water, free from heavy metals, as crop nutrient through irrigation and the use of waste water sludge and fermentable organic waste for production of biogas and, if sufficiently purified, biosolids as plant nutrients. Dedicated bio energy crops may increase the soil carbon sequestration, hereby contributing to the reduction of global warming
(McCalmont et al., 2017). In this way, complete ecological cycles can be created, which utilize all energy sources in optimal ways and minimize solid waste production. The economics, environmental impact and the social acceptance of the practical aspects of ecosystem approach are indispensable for the energy management of these energy systems at different scales and these must be taken into consideration when planning regional development projects. Bioenergetics plays an important role in circular economy that forms the basis of a sustainable society, based on the renewable energy - finished product - zero waste system and sustainable use of ecosystem services. The operation of this system is ensured by the environmentally conscious production of commodities based on life cycle assessment (LCA), waste management focusing on recycling and waste to energy programs. It is important to take into consideration the principle of plurality in the use of renewable energies, which requires the complementary use of these types of energy not only for economic, but also for environmental and energy security reasons (Sovacool and Murkherjee, 2011; Némethy, 2018).

Bioenergy itself is diverse and closely linked to agriculture, forestry, wastewater treatment, energy recovery from solid waste and industries (waste heat) and services producing organic, compostable waste. Biomass supplies an increasing share of electricity and heat and continues to provide the majority of heating produced with renewable resources. Trends of using biomass include increasing

Contact address: $\quad$ Dr. Sándor Némethy, Viola utca 10, 8784 Kehidakustány, Hungary, Telephone: +36-20-5537783, +46-73-3467525; e-mail: samdor@conseravtion.gu.se 
consumption of solid biomass pellets (for heat and power use) and use of biomass in combined heat and power (CHP) plants and in centralized district heating systems. Due to the aforementioned complexity and limitations of bioenergetics, biomass production should be combined with other renewable energy sources such as geothermal energy, solar cells, wind turbines, hydroelectric power plants and non-polluting high-tech waste incinerators (Némethy, 2018). It can also be the key to solving the "energy trilemma" . In a holistic and integrated food and energy system there is no conflict between bioenergy production and food supply; the ecological footprint is sufficiently small. A transition is needed from fossil fuel centred, ineffective and inefficient societies to the ecologically and economically viable, recycling society. Technological developments (in conversion, as well as longdistance biomass supply chains such as those involving intercontinental transport of biomass-derived energy carriers) can dramatically improve competitiveness and efficiency of bioenergy (Hamelinck et al., 2004; Faaij 2006).

Shortage of natural wood is a common problem in different countries - particularly for forest industries in developed countries and for fuel production in developing countries. The agricultural expansion of the last decades resulted in deforestation and forest degradation and the illusion of economic development, seemingly benefiting billions of people in a short term and causing severe environmental and social problems for future generations. The rapid expansion of agriculture for food, fuel and other products has resulted in significant greenhouse gas (GHG) emissions. An estimated 4 to 14 per cent of global GHG emissions are associated with deforestation and degradation, making agriculture a major component of the human factors of global climate change mitigation efforts (Vermeulen et al., 2012). It is therefore critical that we fully understand the relationship between the development of the agriculture sector and its impact on forests and propose appropriate integrated solutions. Fast growing woody bioenergy plantations can produce large quantities of biomass in a relatively short time. The raw material produced is suitable for direct combustion, gasification, pyrolysis, ethanol or methanol production yielding heat, charcoal, pyrolysis oil (biocrude), green electricity and bio-propellants. Current liquid fuels are produced nearly entirely from starch or sugars - mainly from corn, sorghum and sugarcane - and from oils extracted from soy, camelina and aquatic plants (for more comprehensive source, see, e.g., Busic et al., 2018; Barnwal and Sharma, 2005; Cerveró et al., 2008, respectively). However, the importance of cellulosic materials produced from perennial grasses and trees is increasing even in the production of liquid biofuels. Woody biomass is usually used in form of pellets and wood chips for combustion in power plants, but there is a great potential for production of liquid biofuel, biochar and pyrolysis oils as well. Although woody biomass production is environmentally sustainable in terms of carbon dioxide emissions and low pollution, the impact of the expansion of this industry on wildlife habitats has not been sufficiently investigated so far. To determine possible wildlife impacts, a number of questions and scenarios based

\footnotetext{
1 The World Energy Council's definition of energy sustainability is based on three core dimensions - energy security, energy equity, and environmental sustainability - this is the "energy trilemma".
}

on the current status of ecosystems and the carrying capacity of ecosystem services should be taken into consideration. The most important factors include change of land use, the type of energy crop and the cultivation method:

1. The extent of land use change:

a) replacement of natural vegetation by bioenergy crops,

b) land reclamation - remediation, conversion of industrial land to agricultural land,

c) change of managed forestry to intensive monoculture,

d) the type of bioenergy crop produced.

2. The biodiversity status of the site.

3. The productivity of the site in terms of fertility, growing season and moisture.

4. The intensity and inputs of production.

5. The size and proportions of the landscape areas occupied by the feedstock.

6. The length of rotation cycles (frequency of harvest).

7. Wildlife species and communities currently occupying the site:
a) size and dynamics of populations,
b) conditions of survival,
c) ecological advantages of invasive species induced by anthropogenic changes.

8. The direct impact on current or projected future wildlife habitats:

a) complementation,

b) improvement,

c) change of habitat structure - having either adverse or beneficial effects depending on the current state of the habitats at the establishment of bioenergy plantations,

d) elimination of habitats - adverse impact.

9. Willingness to trade some production potential for wildlife habitat conservation.

10. Potential to maintain elements of habitat structure (e.g. snags, buffers, etc.) on the landscape

Another important factor of biomass energy from FAO's point of view is that it creates a lot of jobs. By creating or improving rural infrastructure, it opens new opportunities. Also, it has a tremendous potential for rehabilitating degraded land, since several plant species are suitable for phytoremediation, and such a plant, if used for energy, has an added value. It makes land reclamation economically even more viable.

\section{Short Rotation Forestry (SRF), Short Rotation Coppicing (SRC), Agroforestry and Polycyclic Arboriculture: agriculture or forestry? - ecological implications}

The planting of woody energy crops requires thorough knowledge of the ecological conditions and the economic environment such as the mapping of the upstream market, which is essential for developing sustainable business strategies. It is safe to cultivate these plants where, within a radius of up to 50 to $80 \mathrm{~km}$, the energy-producing sector that needs chips appears. Furthermore, the realistic estimation of possible trade-offs regarding environmental sustainability is important (e.g. the degree of biodiversity 
and the short-term efficiency of the cultivation methods). In addition to thermal power plants, more and more municipalities want to rely wholly or partly on biomass, which will provide a safe market for chips from woody plantations. Woody biomass production can be established in different forms, but not all of them can be considered as fully ecological structures, since their impacts on ecosystem services, habitats and landscape structure are different.

\section{Short Rotation Forestry}

Short-rotation forestry (SRF) is a fast-expanding sustainable silvicultural practice where high-density plantations of fastgrowing tree species produce woody biomass preferably on low quality agricultural land less suitable for food production or on fertile but degraded forest soils. In SRF systems trees are cut when they reach a size of typically 10 to $20 \mathrm{~cm}$ diameter at breast height, which usually takes between 8 and 20 years depending on the tree species and growing conditions. While short rotation coppicing (SRC) cuts the tree back to a stool to promote the growth of multiple stems, on a regular cycle of roughly 2-4 years or sometimes every year, SRF makes it possible to practice something more closely akin to conventional forestry, though on a shorter timescale (Facciotto et al., 2014). Thus, the timescale of the production is between SRC and conventional forestry, which has several ecological advantages; even if the short-term biomass production is lower than in intensive SRC systems. This has the effect of retaining the high productivity of a young plantation, but increasing the wood to bark ratio. Applying similar techniques to sustainable conventional forestry practices, it is currently proposed that only the stem wood would be removed from the site, while the bark stripped during harvesting together with other residues should be left on site to return nutrients to the soil preventing soil depletion. Greater attention to SRF could offer a way to provide forest industries with enough wood resources and people in the developing world with enough fuel, while conserving natural forests (Christersson, 2005).

\section{Short Rotation Coppicing}

Fast-growing tree species can be cut down to a low stump (or stool) when they are dormant in winter and start producing many new shoots in the following growing season. Short rotation coppicing (SRC) is an intensive and well controlled cultivation method for production of woody biomass and has a rotation period of about 25 years and with an annual woody production of at least 10 metric tonnes of dry matter or 25 cubic meter per hectare, depending on the species and growing conditions (Table 1).

This system has been developed to provide large-scale biomass production instead of conventional forestry, where due to economic and ecological difficulties in creating optimal water and nutrient conditions, competition from herbaceous plants and other tree species and biotic and abiotic damage are serious threats for the entire growth and, therefore, the biomass producing potential of conventional forestry is not sufficiently utilized. Ecologically, SRC cultivations are closer akin to arable farming than to conventional forestry. Many species and varieties are suitable for providing biomass for energy purposes, but in practice, few species can be selected for the establishment of SRC energy plantations. The main criteria for bioenergy plants include high rate of growth, good frost tolerance, simple and economical reproducibility, high adaptability, disease-resistance to pests and easy harvesting. The three most successfully used trees for SRC systems are willow (Salix sp.), poplar (Populus sp.) and black locust (Robinia pseudo-acacia L.); other trees include eucalyptus, alder (Alnus sp.), ash (Fraxinus sp.), and birch (Betula sp.).

Willow is the most commonly used tree in SRC plantations for energy in Europe due to a number of advantageous properties such as fast growth and high yields, suitability for coppicing, wide tolerance of soil $\mathrm{pH}$ and structure $(\mathrm{pH} 5$ to 7.5, from heavy clays to lighter soils, respectively), tolerance of highly anoxic (waterlogged) conditions and elevated nutrient and heavy metal concentrations (suitability for phytoremediation). Willow requires humid conditions and grows best in cool-temperate climate, but there are clones suitable for warmer climate conditions such as Eastern and Central Europe.

Poplar is the second most important woody plant grown for bioenergy in Europe (Elbersen et al., 2012). Its ecological preferences are different from willow, including areas with milder climates (e.g. Central and Southern Europe), sandier and drier soils due to lower water needs of poplar than willow. The plantations are less dense, and the rotation periods are substantially longer (10 to 15 years) than for the willow SRC systems. Poplars bloom early, well before

Table 1 Short rotation coppice (SRC) in Europe

\begin{tabular}{|l||c|c|c|}
\hline \multicolumn{1}{|l||}{ Traits } & \multicolumn{2}{c|}{ Species } \\
\cline { 2 - 4 } & willow & poplar & black locust \\
\hline \hline Crop density stools per hectare & $18-25,000$ & $10-15,000$ & $8-12,000$ \\
\hline Rotation years & $3-4$ & $1-3$ & $2-4$ \\
\hline Avg. butt diameter at harvest (mm) & $15-30$ & $20-40$ & $20-50$ \\
\hline Avg. height at harvest (meter) & $3.5-5.0$ & $2.5-7.5$ & $2.0-5.0$ \\
\hline Growing stock at harvest (fresh metric tons per hectare) & $30-60$ & $20-45$ & $15-40$ \\
\hline Moisture content (\%) of dry weight & $50-55$ & $50-55$ & $40-45$ \\
\hline Part of Europe (main cultivation areas) & $\begin{array}{c}\text { Northern Europe, } \\
\text { British Islands }\end{array}$ & Central Europe & $\begin{array}{c}\text { Central and Southern } \\
\text { Europe }\end{array}$ \\
\hline
\end{tabular}

Source: Proceedings of First Conference of the Short Rotation Woody Crops Operations Working Group, Paducah, KY, September 23-25, 1996 (modified) 
budding; wind pollinators. Their fruits develop rapidly, ripening 3 to 6 weeks after flowering. Due to the white cotton wool - like flyers, the seeds are able to spread on large areas by the wind. The flyer detaches itself from the seed soon after landing. On uncovered soil, in a humid environment, some poplar species germinate within 1 to 2 days. About 35 poplar species are known, which belong to the deciduous vegetation of the northern temperate zone. Despite the small number of species, it is a highly differentiated genus both morphologically and ecologically. Most poplars are fast growing pioneer species in the temperate regions and the arid regions of the subtropics, which mainly grow on the alluvial soils of riverbeds, flood plains and deltas. Close-range species are easily crossed and, therefore, so many natural and artificial hybrids are known, whose identification may be extremely difficult in many cases. The most widely cultivated noble poplar varieties are $P$. deltoides, $P$. nigra, $P$. deltoides $\times P$. nigra hybrids, and $P$. deltoides $\times P$. trichocarpa hybrids. Poplar plantations are less dense, and the rotation periods are substantially longer (4 to 6 or 10 to 15 years) than for the willow SRC systems.

Black locust (Robinia pseudoacacia L.), originating from the Eastern United States, was introduced to Europe during the $17^{\text {th }}$ century first as ornamental tree but later conquered vast areas by extensive plantations for timber production and by natural propagation mostly in central and south-eastern parts of Europe. Black locust is quite drought-resistant, nitrogen fixing, able to grow on bare soils under extreme conditions, which makes it ideal for soil regeneration and reclaiming former mining sites. It is fast-growing with good coppice ability after harvest, and its high wood density makes it very useful as SRC for bioenergy production. Even if black locust has invasive properties, the interest is increasing for Robinia SRC on agricultural land, especially in areas where land reclamation is required. In view of the recently emerging debate regarding the invasive character of black locust, its multi-purpose use must be emphasized, particularly as timber, bio-energy feedstock, raw material for pulp, as melliferous tree, an important plant for phytoremediation of both heavy metals and Polycyclic Aromatic Hydrocarbons (PAHs), soil improvement due to its nitrogen fixing ability, and even as a natural habitat - cover for wildlife, browse for deer and nesting place for birds (Szemethy et al., 2003; Mátrai et al., 2004). The economic viability of biomass production by black locust has been debated many times (particularly in SRC systems), but established in a multipurpose, ecocycle-based agricultural system where its invasive character is carefully controlled and its usefulness is fully utilized (applying even clone selection for site-adaptation and best possible performance), both environmental sustainability and profitability should be guaranteed.

Eucalyptus is a genus of fast-growing tree species originated from Australia, which contains more than 700 species. This tree has been extensively planted in southern Europe and even in South Africa for pulp and paper production and its use for wood biomass is gaining interest not only in southern Europe, but also in higher latitudes e.g. in the UK and Ireland, where more coldtolerant clones (E. gunnii and E. nitens) are being cultivated. Eucalyptus SRC plantations are traditionally planted in single-stem plantations in $3 \times 3$ meter distances (or similar) and harvested after 7 to 12 years for pulp production, but in some cases, particularly for energy feedstock, very short rotation of 2 to 4 years is applied, which resembles the willow coppice systems.

\section{Agroforestry}

Agroforestry is a complex land-use system in which woody perennials are deliberately integrated with crops and/ or livestock on the same land-management unit either in a spatial mixture or in a temporal sequence. There are both ecological and economic interactions between the woody and non-woody components in agroforestry, which is based on four key features: competition, complexity, profitability and sustainability (Oelbermann et al., 2004). "Agroforestry is a dynamic, ecologically based, natural resource management system that, through the integration of trees in farm- and rangeland, diversifies and sustains smallholder production for increased social, economic and environmental benefits" (Leakey, 1996). Agroforestry practices can be divided into two groups - those that are sequential, such as fallows, and those that are simultaneous, such as alley-cropping (Cooper et al., 1996). The sustainable management of the competition between trees and crops for light, water and nutrients is the plant-physiological determinant of successful agroforestry systems. Simultaneous agroforestry systems are more susceptible to competition than sequential ones.

In agroforestry systems the requirement of fast growth is slightly less important than in SRC systems and this allows a greater diversity of trees and the non-woody components. This is particularly important regarding the functions of agroforestry and the possibilities to create new habitats and maintain or increase the biodiversity of agroecosystems. Using indigenous trees with high-value products in agroforestry systems enhances profitability, particularly those that can be marketed as ingredients of several finished products.

\section{Polycyclic arboriculture - permanent polycyclic tree farms}

The advantages of these artificial forests compared to intensive poplar plantations are addressed not only to technicians, farmers and ordinary citizens, but also and above all to regional and national political decision makers, who could focus on the development of these plantations that combine wood production and environmental improvement. These mixed plantation methods with valuable broadleaved species and poplar clones have been implemented both in tree farming plantations and in agroforestry systems (Facciotto et al., 2014). This type of tree farming is called "polycyclic plantation", which contains main crop trees, with different cultivation cycles, coexisting in the same plantation area with:

a) very short rotation trees for biomass production (SRCs);

b) short rotation trees for veneer production (poplar clones);

c) medium long rotation trees for timber and high quality veneer production (walnut and other valuable broadleaved species).

Higher biodiversity and species composition make polycyclic plantations more resistant to environmental stress and less demanding in terms of energetic input, they are innovative, and more sustainable than monocultures. 


\section{Connecting systems of woody biomass production and environmental management}

\section{Natural wastewater cleaning and irrigation with biologically cleaned wastewater}

Short rotation forests, short rotation coppice plantations and even agroforestry are excellent objects for natural wastewater cleaning. Agricultural deployment of wastewater for irrigation is based on the value of its constituents, which are used as fertilizers. However, crop irrigation with insufficiently treated wastewater may result in health risks. Use of untreated sewage effluent for irrigation exposes the public to the dangers of infection with a variety of pathogens such as protozoa, bacteria and viruses. Thus, the benefit of wastewater reuse is limited by its potential health hazards associated with the transmission of pathogenic organisms from the irrigated soil to crops, to grazing animals and humans (Gupta et al., 2009; Qadir et al., 2010). Wastewater should satisfy some quality indicators such as chemical structure, availability of gases, content of organic substances and bacteria, muddiness, temperature, etc. Those indicators depend on salt tolerance of the cultivated crops, chemical structure and water permeability of the soil, drainage of the ground, characteristics of rainfalls, background content of heavy metals, meteorological and hydro-geological circumstances, irrigation technology, applied agricultural techniques, etc. The suitability of the treated water for irrigation can be determined on the basis of results from chemical analyses, vegetation and field experiments, as well as comparing various crops irrigated with clean and treated wastewater during a longer period of time (Panoras et al., 1998, 2003). Thus, biologically cleaned wastewater is a substantial resource.

\section{Utilization of short-rotation forests as vegetation filters for waste products}

This holistic system is strongly supported in Sweden (Perttu and Obarska-Pempkowiak 1998; Dimitriou and Aronsson, 2004). After biological cleaning, a simple sand filter system or other particle filters can remove particles - if needed and low concentration of disinfectants will assure the appropriate water quality. This water should be almost entirely free of bacteria and can be used for irrigation. For the safety of public health and the protection of groundwater and surface watercourses and natural habitats the environmental legislation in all developed countries requires the thorough control and environmental consequence analysis as well as the systematic monitoring of the re-use of partially cleaned wastewater, which together with natural mineral-based soil improvement substances (Némethy, 2019) can maintain bio energy plantations without any other artificial fertilizers. Furthermore, the potential for phytoremediation should be taken into consideration, since waste products can also contain polluting heavy metals and organic pollutants, which some willow and poplar clones are able to absorb efficiently. When wood from this type of plantation is burned, heavy metals can be extracted from both the fly ash and bottom ash. However, this process is not yet economical, so today most of the ashes are deposited at safe city waste disposal sites.

\section{Phytoremediation with woody plants combined with biomass production for energy}

Phytoremediation is a fast developing and expanding environmental technology for contaminated soils, groundwater, and wastewater that is both low-tech and lowcost, defined as the engineered use of green plants (including grasses, forbs, and woody species) to remove, contain, or render harmless environmental contaminants such as heavy metals, traceelements, organic compounds, persistent organic pollutants (POPs) and radioactive compounds in soil surface waters and groundwater (Watanabe, 1997). There are several phytoremediation techniques with variable effectiveness depending on the biochemical and physiological properties of the plant and the pollutant.

Phytodegradation also known as phytotransformation, when pollutants or complexes are broken down to simple compounds and then transferred into the plant tissue, is the most effective technique against organic contaminants, including certain POPs (Watanabe, 1997), while phytoextraction and phytostabilisation are best suited to remove inorganic pollutants (e.g. heavy metals) but might be effective even for POPs (Gyulai et al., 2013).

Phytovolatilization, a process, in which plants take up contaminants from soil and release them as volatile form into the atmosphere through transpiration, and rhizofiltration, a technique of utilizing plant roots to absorb, concentrate, and precipitate pollutants (often toxic metals) from ground water or polluted effluents, are effective both with inorganic and even organic contaminants. Furthermore, the safe use of transgenic plants might be possible for detoxification of organic pollutants (Merino et al., 2008).

Thus, phytoremediation technologies involve processes, which are able to isolate, destroy, transport, and remove organic and inorganic pollutants from contaminated media (Echereme et al., 2018).

The landscape and ecosystem approach and the role of biodiversity in the cultivation of woody bioenergy crops - ecological and economic implications, impact on wildlife habitats

There are several issues concerning the environmental, socio-cultural and economic sustainability of woody biomass production connected to land use, protection and/or creation of wildlife habitats, conservation and remediation of wastelands and derelict cultural landscapes. These problems include the land use where biomass production is established instead of cultivating agricultural crops for food, the limited suitability of short rotation coppice (SCR) plantations as wildlife habitats and alteration of the structure and appearance of cultural landscapes (Némethy and Walas, 2016).

\section{The Biodiversity - Ecosystem Function and woody bioenergy feedstock production}

Willow, due to its wide ecological tolerance, ecophenotypic variability, large number of available species and clones, fast growth, and tolerance of environmental stress and certain similarities to grassland systems, in SRC systems creates suitable structures for testing the biodiversity-ecosystem function (BEF) theory (Weih et al., 2019), which often lacks a sound understanding and comprehensive interpretation 
of the complex mechanisms behind the observed patterns of diversity-productivity relationships. It is important to take into consideration the complete set of factors within each category of BEF components (Fig. 1). According to the BEF theory, levels of ecosystem functions (e.g., primary and secondary productivity, nutrient cycling, decomposition) and the stability of those functions depend directly on all levels of biodiversity, including diversity of all biota at the level of genotypes, species, and functional groups, which are considered as sets of physiologically or morphologically similar species. Ecosystem functions are conceived as a subset of ecological processes and ecosystem structures, which are typically estimated from measures of stocks such as plant biomass or crop nutrients, in response to vascular plant diversity.

While woody bioenergy plantations and some perennial feedstocks can improve soil quality and biodiversity, reduce greenhouse gas emissions and enhance water quality, some large-scale industrial models of modern biofuel production can negatively impact ecosystem services through the excessive use of synthetic fertilizers and agrochemicals, grassland conversion and deforestation (Pacheco et al., 2012).

Particularly serious concerns were raised concerning food security, especially in regions with widespread poverty, political uncertainty, and fragile agricultural systems, which are likely to be exacerbated with accelerating climate change (Brown and Funk, 2008). However, the right choice of bioenergy crops, the territory of cultivation and cultivation methods might counteract the harmful environmental and social effects of monoculture, particularly if connected to phytoremediation and soil improvement programmes often creating new employment opportunities. A number of studies have demonstrated, that there is considerable potential for increasing economically and ecologically viable bioenergy production even further, to meet a substantial fraction of future energy needs without compromising any aspect of sustainability (Smeets et al., 2007; Somerville et al., 2010). Thus, bio-energy development may offer developing countries many advantages, ranging from energy security to poverty reduction, infra-structure development and economic growth.

\section{Woody bioenergy crops, biodiversity and wildlife habitats}

According to quite recent field experiments, species abundance in SRC plantations can be more heterogeneous than in arable lands and therefore, SRC plantations form novel habitats leading to different plant species composition compared to conventional land uses. Their landscape-scale value for biodiversity changes depending on harvest cycles and over time. As a structural landscape element, SRC plantations can positively contribute to biodiversity in rural areas, especially in land use mosaics where these plantations are admixed to other land uses with dissimilar plant species composition such as arable land, coniferous forest and even mixed forests (Baum et al., 2012). However, the ecological effects of SRC plantations are dependent on climate and soil conditions, the ecological preference of the cultivated maincrop species, rotation cycles, the species composition of the plantations, and the cultivation methods, including irrigation and nutrient supply and the degree of monoculture.

Regarding the effects of bioenergy crop cultivation on wildlife habitats, the conversion of natural ecosystems (e.g.,

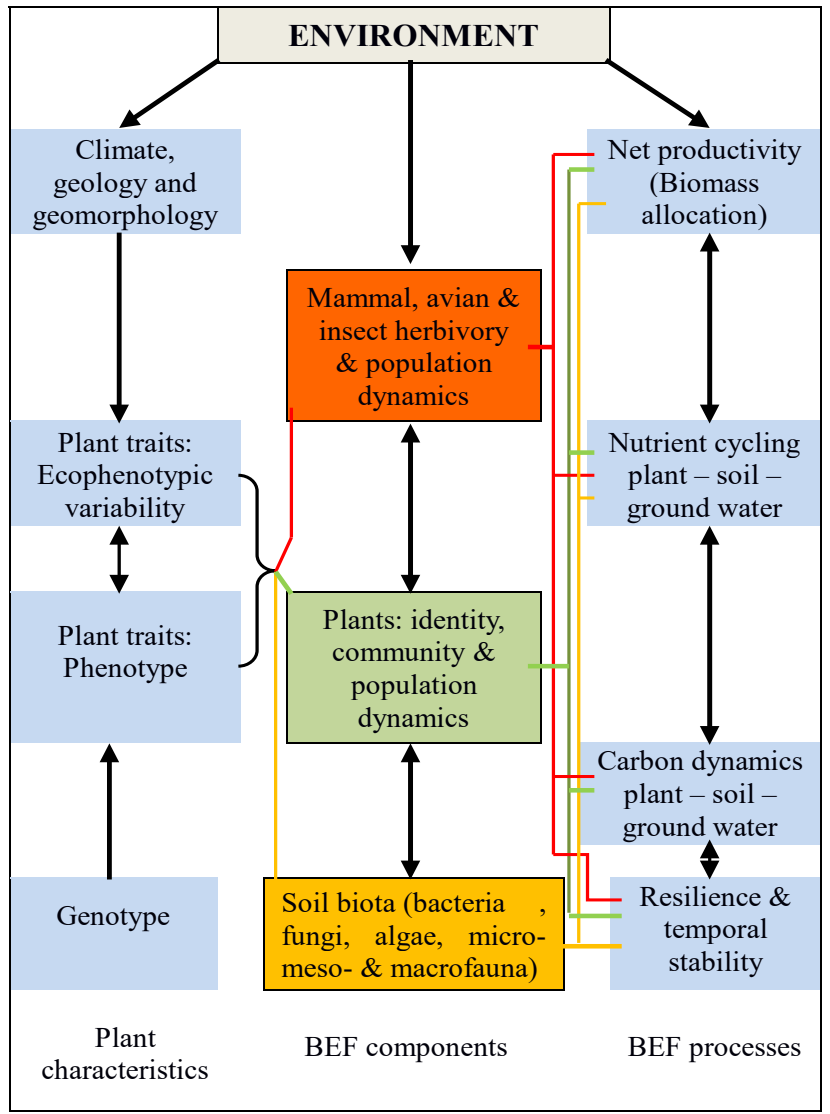

Figure 1 The most important relationships between plant traits and the biodiversity-ecosystem function (BEF) components and processes based on willow short-rotation coppice (SRC) systems. The BEF components are intimately connected to growth and productivity (green); mammal, avian and insect herbivory (above ground trophic interactions, red), and soil biota representing below ground trophic interactions (yellow)

Source: redrawn and substantially modified after Weih et al., 2019

forests, woodlands, grasslands) to ones dominated by crop monocultures is often associated with losses of wildlife habitat and biodiversity. Sustainable game management and forestry actively contributes to maintaining biodiversity. In natural areas where intensive wildlife management is practiced, it is important to maintain the natural ecosystem. Wildlife needs a natural habitat, a feeding, hiding and breeding ground. Therefore, game management can only be successful where these conditions are provided to the wildlife. This means that large areas of forests, diverse habitats with natural waters and sheltered areas, where freemoving wildlife can be maintained, should be preserved for this purpose. In traditional forestry and even in sustainable, organic cultivation of woody bioenergy crops such as longer rotation cycle plantations, agroforestry and polycyclic arboriculture, high energy crops, free of agrochemicals, provide an abundant source of food for animals. In these areas, of course, not only the wildlife to be exploited can find optimal living conditions, but every living creature that makes up the ecosystem (Fig 3). Such carefully managed hunting areas have much greater biodiversity. The number of species 


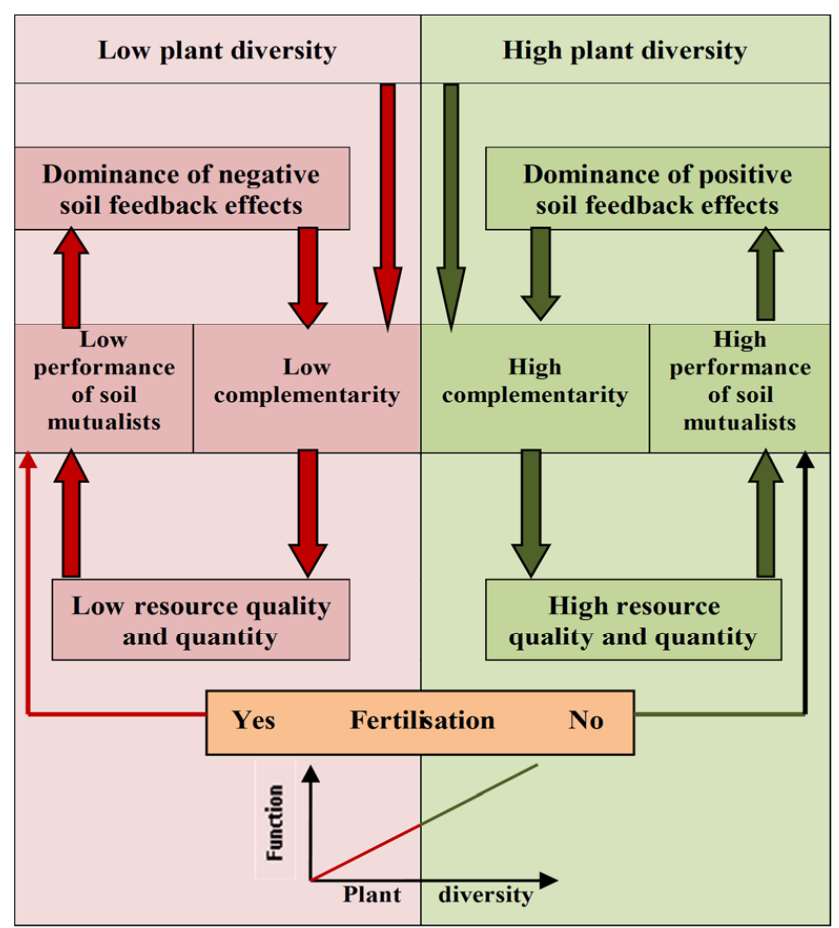

Figure 2 The influence of aboveground - belowground interactions on the positive relationship between biodiversity and ecosystem functioning. Resource use complementarity is higher in high communities with high plant diversity. Mutualists will mitigate or superimpose adverse effects of antagonists on plants (Eisenhauer, 2018; Latz et al., 2012). Artificial fertilisation may have negative effect on the performance of soil mutualists, such as arbuscular mycorrhiza fungi (Collins Johnson, 1993)

Source: redrawn and modified after Eisenhauer (2018)

and the number of individuals is noticeable. At the same time, soil life is enriched, which results in more vegetation. This in turn creates a new habitat for the entire ecosystem. When assessing the ecological viability of bioenergy crop cultivation, the relationships between biodiversity and ecosystem function (BEF) should be determined from the observed characteristics of aboveground - belowground multitrophic interactions, which may substantially improve the often far too mechanistic interpretation of BEF relationships. Thus, the previously mentioned BEF-theory, which has been tested on willow SRC systems (Fig. 1), can be applied in connection with the analysis of the balance between negative and positive plant-soil feedback effects and the consequences for ecosystem functioning (Fig. 2). Research on the connection of biodiversity and plant biomass production showed that plant community biomass was marginally significantly higher in species-rich plant communities than in species-poor ones suggesting varying net soil feedback effects depending on plant diversity (Eisenhauer, 2018). The development of plant biodiversity in SRC is greatly influenced by light availability, which changes at every coppice rotation and the planted area evolves from a bare field to a shrubby vegetation, that later will become similar to a forest with a closed canopy. These changes in the plant community determine the diversity of the fauna, such as bird populations, which evolve from open space to forest communities, continuously co-existing in shifting ratios. Arthropods and small mammals can satisfy their habitat needs from SRC while birds and large mammals only use the SRC for a limited number of resources. Hence, cultivation of bioenergy feedstocks could compensate for habitat losses for species that inhabit shrubby areas or regenerating forests (Tarr et al., 2017).

Furthermore, the previous use of land and the preceding vegetation cover may play an important role in the development of additional vegetation in the area of bioenergy plantations, since residual plants (seeds, roots, remaining stubbles, etc.) may develop new populations together with the newly established bioenergy plantations, contributing herewith to greater biodiversity and the development of more variable wildlife habitats.

From the above analyses it is obvious, that the value of wildlife habitats depends on the similarity of habitat properties to the natural, undisturbed state or the ability to develop sustainable, with the surrounding natural ecosystems compatible substitutions in cultivated areas (Fig. 3). The degree of plant architectural complexity: if higher, the habitat contains more strata, more and diverse branches, the wildlife is characterized by more microhabitats with higher chance for niche segregation, and more species; lower complexity results in habitats with simple layer, linear structures of wildlife, fewer microhabitats, and niches for fewer species (Fargione et al., 2009).

In case of cultivation of woody bioenergy feedstocks, the value of wildlife habitats depends on the planted material (i.e., alien, invasive vs. native, non-invasive), the timing and frequency of harvest and disturbances, cultivation factors, which include the type of the habitat, plant diversity, the invasive character of the ability of post-harvest recovery, habitat refugia as a function of the sizes of unharvested areas within the cultivated fields, the landscape content and the impact of cultivation methods on wildlife. Furthermore, plant biodiversity depends on the aboveground - belowground trophic interactions, which can be maintained only with sustainable, preferably with organic cultivation methods. Even if the biomass production is lower in ecologically managed systems, additional benefits (food, raw material for crafts, etc.) will compensate for these losses.

\section{Conclusions}

Linking woody bioenergy plantations and phytoremediation can greatly increase the sustainability of biomass production by improving soil and/or groundwater quality, removing hazardous substances from the environment, keeping biomass production in those areas, which are less suitable for food production.

In woody biomass production, longer rotation cycles and greater biodiversity are particularly beneficial in agroforestry systems and polycyclic arboriculture or in those short rotation plantations, where the length of rotation cycles allows newly established plant communities to develop asatisfactory level of biodiversity suitable for habitats.

When assessing the impact of bioenergy crop production of wild life habitats taking into consideration the demand for bioenergy, the following factors are the most important:

- estimating gains and/or losses in the number of habitats for individual species at the landscape scale, based 


\begin{tabular}{|c|c|c|}
\hline \multicolumn{3}{|c|}{ Wildlife Habitat Value } \\
\hline Lower & & Higher \\
\hline Cropland & Habitat type & Diverse native habitats \\
\hline Exotic monocultures & Plant diversity & Diverse native grasslands/forests \\
\hline Alien, invasive & Invasiveness of planted material & Native, non-invasive \\
\hline Breeding/nesting season & Harvest and disturbance timing & Late fall/early spring \\
\hline Multiple harvests in one year & $\begin{array}{l}\text { Harvest and disturbance } \\
\text { frequency }\end{array}$ & Single harvest in $\geq 1$ year \\
\hline Little/no remaining stubble & $\begin{array}{l}\text { Stubble height, post-harvest } \\
\text { plant architectural complexity }\end{array}$ & Tall stubble or regrowth \\
\hline $\begin{array}{l}\text { No unharvested area in field or } \\
\text { nearby }\end{array}$ & $\begin{array}{l}\text { Habitat refugia, formation of } \\
\text { connection corridors among } \\
\text { more natural but fragmented } \\
\text { habitat patches at least } \\
\text { temporally }\end{array}$ & Unharvested area within field \\
\hline Isolated patch/field & $\begin{array}{l}\text { Landscape Content } \\
\text { Wildlife Impact }\end{array}$ & nplex of habitat patches/fields \\
\hline Higher & & Lower \\
\hline Native prairie/forest/wetland & Land use replaced with biomass crop & Marginal cropland \\
\hline High input & Use of fertilizers & Minimal input \\
\hline High input & Use of Pesticides & Minimal input \\
\hline Annual crops - high erosion & Soil Erosion and Sedimentation & erennial plants - low erosion \\
\hline Intensive monocultures & Phytoremediation of Degraded Soils & Selected, mixed species \\
\hline
\end{tabular}

Figure 3 The value of wildlife habitats depending on the cultivation factors of bioenergy crops. For each factor, the qualities associated with greater wildlife benefit (or less impact) are listed on the right side of the figure, and the qualities that are associated with less wildlife benefit (or greater impact) are listed on the left side of the figure

Source: modified after Fargione et al., 2009

on a sufficiently large demand of bioenergy on realistic levels;

- the effect of different bioenergy portfolios on wildlife habitats;

- relationships between specific sources of biomass and individual species;

- possibilities for ecocycle-based organic bioenergy feedstock production in SRC systems (e.g. irrigation of woody bioenergy crops with purified wastewater) linked to conservation of habitats;

- establishing connections of natural ecosystems and artificial ecosystems created by bioenergy crop cultivation: enlarging suitable habitats and increasing habitat complexity, which may yield in great potential for ecological networks;

- potential in greening agriculture.
BROWN, M. E. - FUNK, C. C. 2008. Food Security Under Climate Change NASA Publications. 131. http://digitalcommons. unl.edu/nasapub/131

BUŠIĆ, A. - KUNDAS, S. - MORZAK, G. BELSKAYA, H. - MARĐETKO, N. - ŠANTEK, M.I. - KOMES, D. - NOVAK, S. - ŠANTEK, B. 2018. Recent Trends in Biodiesel and Biogas Production. In Food Technol Biotechnol., vol. 56, 2018, no. 2, pp. 152-173. https://doi. org/10.17113/ftb.56.02.18.5547

CERVERÓ, J.M. - COCA, J. - LUQUE, S. 2008. Production of biodiesel from vegetable oils. In Grasas Aceites, vol. 59, 2008, no. 1, pp. 76-83. https://doi.org/10.3989/gya.2008. v59.i1.494

CHRISTERSSON, L. 2005. Plant physiological aspects of woody biomass production for energy purposes. In Verma, K.S. Khurana, D.K. - Christersson, L. eds. Short rotation forestry for industrial and rural development. Nauni, Solan, Himachal Pradesh, India, Indian Society of Tree Scientists, 2005.

COLLINS JOHNSON, N. 1993. Can Fertilization of Soil Select Less Mutualistic Mycorrhizae? In Ecological Applications, vol. 3, 1993, no. 4, pp. 749-757. https://doi. org/10.2307/1942106

COOPER, P.J.M. - LEAKEY, R.R.B. - RAO, M.R. - REYNOLDS L. 1996. Agroforestry and the mitigation of land depletion in the humid and sub-humid tropics of Africa. In Experimental Agriculture, 1996, no. 32, pp. 235-290.

DIMITRIOU, I. - ARONSSON, P. 2004. Nitrogen leaching from Short-Rotation Willow Coppice after intensive irrigation with wastewater. In Biomass and bioenergy, vol. 26, 2004, no. 5, pp. 433-441.

ECHEREME, C.B. - IGBOABUCHI, N.A. IZUNDU, A.I. 2018. Phytoremediation of Heavy Metals and Persistent Organic Pollutants (POPs): A Review. In ljsrm. Human, vol. 10, 2018, no. 4, pp. 107-125. www.ijsrm.humanjournals.com

EISENHAUER, N. 2018. Abovegroundbelowground interactions drive the relationship between plant diversity and ecosystem function. In Research Ideas and Outcomes, 4:e23688. https://doi. org/10.3897/rio.4.e23688

ELBERSEN, B. - STARTISKY, I. - HENGEVELD, G. - MART-JAN SCHELHAAS, M-J. NAEFF, H. 2012. Atlas of EU biomass potentials Deliverable 3.3: Spatially detailed and quantified overview of EU biomass potential taking into account the main criteria determining biomass availability from different sources. Biomass role in achieving the Climate Change \& Renewables EU policy targets. Demand and Supply dynamics under the perspective of stakeholders. IEE 08653 SI2. 529241. https://ec.europa.eu/energy/intelligent/ projects/sites/iee-projects/files/projects/ 
documents/biomass futures atlas of technical and economic biomass potential en.pdf

FAAIJ, A.P.C. 2006. Modern biomass conversion technologies. In Mitig. Adapt. Strat. Global Change., 2006, no. 11, pp. 335-367.

FACCIOTTO, G. - MINOTTA, G. - PARIS, P. - PELLERI, F. 2014. Tree farming, Agroforestry and the New Green Revolution. A necessary alliance. Proceeding of the II International Congress of Silviculture: Designing the future of the forestry sector; Florence, vol. 2, 2014. http://dx.doi.org/10.4129/2cis-gf-tre

FARGIONE, J.E. - COOPER, T.R. - FLASHPOHLER, D.J. - HILL, J. LEHMAN, C.-MCCOY,T.-MCLEOD, S. - NELSON, E.J.-OBERHAUSER, K.S. - TILMAN, D. 2009. Bioenergy and Wildlife: Threats and Opportunities for Grassland Conservation. In BioScience, vol. 59, 2009, no. 9, pp. 767-777. https://doi.org/10.1525/bio.2009.59.9.8 GUPTA, N. - KHAN, D.K. - SANTRA, S.C. 2009. Prevalence of intestinal helminth eggs on vegetables grown in wastewaterirrigated areas of Titagarh, West Bengal, India. In Food Control, 2009, no. 20, pp. 942-945.

GYULAI, G. - BITTSÁNSZKY, A. - SZABÓ, Z. - WATERS, L. JR. GULLNER, G. - KAMPFL, G. - HELTAI, G. - KOMÍVES, T. 2013. Phytoextraction potential of wild type and 35S-gshl transgenic poplar trees (Populus $\times$ Canescens) for environmental pollutants herbicide paraquat, salt sodium, zinc sulfate and nitric oxide in vitro. In International Journal of Phytoremediation, vol. 16, 2013, no. 4. https://doi.org/10.1080/15226514.2013.783553

HAMELINCK, C.N. - SUURS, R.A.A. - FAAIJ, A.P.C. 2004. Technoeconomic analysis of international bio-energy trade chains. In Biomass Bioenergy, 2004, no. 29, pp. 114-134.

LATZ, E. - EISENHAUER, N. - RALL, B. - ALLAN, E. - ROSCHER, C. SCHEU, S. - JOUSSET, A. 2012. Plant diversity improves protection against soil-borne pathogens by fostering antagonistic bacterial communities. In Journal of Ecology, vol. 100, 2012, no. 3, pp. 597604. https://doi.org/10.1111/j.1365-2745.2011.01940.x

LEAKEY, R.R.B. 1996. Definition of agroforestry revisited. In Agroforestry Today, vol. 8, 1996, no. 1, pp. 5-7.

MÁTRAI, K. - SZEMETHY, L. - TÓTH, P. - KATONA, K. - SZÉKELY, J. 2004. Resource use by red deer in lowland nonnative forests, Hungary. In Journal of Wildlife Management, vol. 68, 2004, no. 4, pp. 879-888.

MCCALMONT, J.P. - HASTINGS, A. - MCNAMARA, N.P. - RICHTER, G.M. - ROBSON, P. - DONNISON, I.S. - CLIFTON-BROWn, J. 2017. Environmental costs and benefits of growing Miscanthus for bioenergy in the UK. In Glob Change Biol Bioenergy, vol. 9, 2017, no. 3, pp. 489-507. Epub 2015 Aug 18. Review. https://doi.org/10.1111/ gcbb.12294 PMID: 28331551

MERINO, I. - CAMPOS, V.M. - CASADO, R. - PACIOS, L.F. - GOMEZ, L. 2008. Review. Phytoremediation of organic pollutants. In Spanish Journal of Agricultural Research, vol. 6, 2008, no. S1, pp. 38. https:// doi.org/10.5424/sjar/200806S1-372

NÉMETHY, S. - WAŁAS, B. 2016. Bioenergy crops as new components of rural and agricultural landscapes: environmental and social impact, conservation, cultural heritage and economy. In Journal of Central European Green Innovation, (JCEGI 3(TI)) HU, Hungary. ISSN 2064-3004. NÉMETHY, S. 2018. Bioenergetika társadalmi, gazdasági és környezeti kontextusban (Bioenergetics in the context of society, economy and environment). In Magyar Tudomány (Hungarian Science), vol. 179, 2018, no. 8, pp. 1232-1243.

NÉMETHY, S. 2019. Ásványi alapú talajjavító anyagok jelentősége a szőlészetekben (The importance of mineral-based soil improvement substances in viticulture. In Hungarian). In Értékálló Aranykorona, országos mezőgazdasági szaklapm vol. 19, 2019, no. 3, pp. 16-18. ISSN 1586-9652.

OELBERMANN, M. - VORONEY, R.P. - GORDON, A.M. 2004. Carbon sequestration in tropical and temperate agroforestry systems: a review with examples from Costa Rica and southern Canada. In Agric. Ecosyst. Environ, 2004, no. 104, pp. 359-377.
PACHECO, P. - WARDELL, A. - GERMAN, L. - JOHNSON, F.X. - NEIL, B. - van GELDER, J.W. - SCHWAIGER, H.P. - SCHONEWELD, G.C. OBIDZINSKI, K. - GUARIGUATA, M. R. 2012. Synthesis: Bioenergy, Sustainability and Trade-offs: Can we Avoid Deforestation while Promoting Biofuels? In CIFOR Infobriefs, 2012, no. 54. www.cifor.org PANORAS, A. - A. ZDRAGAS. - A. ILIAS, K. 1998. Anagnostopoulos Microbiological quality criteria for municipal wastewater reuse in agriculture. In Geothenical Scientific Issues, vol. 9, 1998, no. 31, pp. 90-103.

PANORAS, A. - EVGENIDIS, G. - BLADENOPOULOU, S. - MELIDIS, V. - DOITSINIS, A. - SAMARAS, I. - ZDRAGKAS, A. - MATSI, Th. 2003. Corn irrigation with reclaimed municipal wastewater. Selected from papers presented at the $7^{\text {th }}$ Conference on Environmental Science and Technology, 3-6 September 2001, Ermoupolis, Syros island, Greece. In Global Nest: The Int. J., vol. 5, 2003, no. 1, pp. 39-45.

PERTTU, K. - OBARSKA-PEMPKOWIAK, H. eds. 1998. Sewage treatment by means of pine, willow, reed and grass vegetation filters. Proceedings of a joint Polish-Swedish workshop in Starbienino, Poland, 25-28 May 1997. Department of Short Rotation Forestry, Report No. 61. Uppsala, Sweden, SLU.

QADIR, M. - WICHELNS, D. - RASCHID-SALLY, L. - MCCORNICK, P. G. - P. DRECHSEL, P. - BAHRI, A. - MINHAS, P. S. 2010. The challenges of wastewater irrigation in developing countries. In Agricultural Water Management, 2010, no. 97, pp. 561-568.

SMEETS, E.M.W. - FAAIJ, A.P.C. - LEWANDOWSKI, I.M. TURKENBURG, W.C. 2007. A bottom up quick scan and review of global bio-energy potentials to 2050. In Prog. Energy Combust. Sci., 2007, no. 33, pp. 56-106, 329, 790-792.

SOMERVILLE, C. - YOUNGS, H. - TAYLOR, C. - DAVIS, S.C. - LONG, S.P. 2010. Feedstocks for lignocellulosic biofuels. In Science, vol. 329, 2010, no. 5993, pp. 790-792. https://dopi.org/10.1126/ science.1189268.

SOVACOOL, B.K. - MURKHERJEE, I. 2011. Conceptualizing and measuring energy security: A synthesized approach. In Energy, vol. 36, 2011, no. 8, pp. 5343-5355. https://doi.org/10.1016/j. energy.2011.06.043

SUN, W.H. - LO, J.B. - ROBERT, F.M. - CHITTARANJAN, R. - CHUNGSHIH TANG. 2004. Phytoremediation of petroleum hydrocarbons in tropical coastal soils I. selection of promising woody plants. In Environ Sci \& Pollut Res, 2004, no. 11, pp. 260. https://doi. org/10.1007/BF02979634

SZEMETHY, L. - MÁTRAI, K. - KATONA, K. - OROSZ, Sz. 2003. Seasonal home range shift of red deer hinds, Cervus elaphus: are there feeding reasons? In Folia Zoologica, vol. 52, 2003, no. 3, pp. 249-258.

TARR, N.M. - RUBINO, M.J. - COSTANZA, J.K. - MCKERROW, A.J. COLLAZO, J.A. - ABT, R.C. 2017. Projected gains and losses of wildlife habitat from bioenergy-induced landscape change. In GCB Bioenergy, 2017, no. 9, pp. 909-923. https://doi.org/10.1111/gcbb.12383

VERMEULEN, S.J. - AGGARWAL, P.K. - AINSLIE, A. - ANGELONE, C. - CAMPBELL, B.M. - CHALLINOR, A.J. - HANSEN, J.W. - INGRAM, J.S.I. - JARVIS, A. - KRISTJANSON, P. - LAU, C. - NELSON, G.C. THORNTON, P.K. - WOLLENBERG, E. 2012. Options for support to agriculture and food security under climate change. In Environmental Science \& Policy, vol. 15, 2012, no. 1, pp. 136-144. https://doi.org/10.1016/j.envsci.2011.09.003

WATANABE, M. 1997. Phytoremediation on the bank of commercialization. In Environmental Science and Technology, vol. 31, 1997, no. 4, pp. 182A-186A.

WEIH, M. - GLYNN, C. - BAUM, C. 2019. Willow Short-Rotation Coppice as Model System for Exploring Ecological Theory on Biodiversity-Ecosystem Function. In Diversity, vol. 11, 2019, no. 8, pp. 125. https://doi.org/10.3390/d11080125 